\title{
Preserving effect of Loboob (a traditional multi-herbal formulation) on sperm parameters of male rats with busulfan-induced subfertility
}

Soghra Bahmanpour ${ }^{1,2}$, Mojtaba Keshavarz ${ }^{3}$, Farhad Koohpeyma ${ }^{3}$, Parmis Badr ${ }^{4,5}$, Adel Noori6,7, Mohammad Hossein Dabbaghmanesh ${ }^{3}$, Tahereh Poordast ${ }^{2,7}$, Fateme Sadat Najib ${ }^{2,7}$, Najaf Zare ${ }^{2,8}$, Niloofar Namazi ${ }^{2,7}$, Bahia Namavar Jahromi ${ }^{2,7}$

${ }^{1}$ Anatomy Department, School of Medicine, Shiraz University of Medical Sciences, Shiraz, Iran

${ }^{2}$ Infertility Research Center, Shiraz University of Medical Sciences, Shiraz, Iran

${ }^{3}$ Endocrine and Metabolism Research Center, Shiraz University of Medical Sciences, Shiraz, Iran

${ }^{4}$ Pharmaceutical Sciences Research Center, Shiraz University of Medical Sciences, Shiraz, Iran

${ }^{5}$ Phytopharmaceutical Technology and Traditional Medicine Incubator, Shiraz University of Medical Sciences, Shiraz, Iran

${ }^{6}$ Student Research Center, Shiraz University of Medical Sciences, Shiraz, Iran

${ }^{7}$ Department of Obstetrics and Gynecology, School of Medicine, Shiraz University of Medical Sciences, Shiraz, Iran

${ }^{8}$ Department of Biostatistics, School of Medicine, Shiraz University of Medical Sciences, Shiraz, Iran

\begin{abstract}
Objective: Male infertility secondary to exposure to gonadotoxic agents during reproductive age is a concerning issue. The aim of this experimental study was to determine the effect of Loboob on sperm parameters.

Methods: 55 healthy rats were selected, weighted and divided into five groups consisting of 11 rats each. The control group received no medication. Rats in Treatment Group 1 received $10 \mathrm{mg} / \mathrm{kg}$ Busulfan and rats in Treatment Groups 2, 3, and 4 received 35,70 and $140 \mathrm{mg} / \mathrm{kg}$ Loboob respectively in addition to $10 \mathrm{mg} / \mathrm{kg}$ Busulfan. Finally, the sperm parameters and weights of the rats were compared using the Kolmogorov-Smirnov, non-parametric KruskalWallis, and Dunn-Bonferroni tests.

Results: All sperm parameters and weights were significantly decreased among rats receiving Busulfan. All dosages of Loboob were effective to enhance the motility of slow spermatozoa, while only in the rats given 70 and $140 \mathrm{mg} / \mathrm{kg}$ of Loboob saw improvements in progressively motile sperm percentages ( 0.024 and 0.01 , respectively). Loboob at a dosage of $140 \mathrm{mg} / \mathrm{kg}$ improved sperm viability. It did not improve normal morphology sperm or decrease immotile sperm counts. Loboob did not affect mean rat weight.
\end{abstract}

Conclusions: Loboob offered a dose-dependent protective effect on several sperm parameters in rats with busulfan-induced subfertility.

Keywords: infertility, Loboob, male subfertility, sperm, traditional Persian medicine

\section{INTRODUCTION}

Infertility is an important health problem with a prevalence of $10-15 \%$ worldwide (Tansaz et al., 2016). Cancer may lead to infertility through alterations to the proteomic profile of spermatozoa or gonadotoxic agents used in cancer treatment. Moreover, the cancer type and behavior, the kind of cytotoxic agents and dosages used, along with patient age and general health status may affect the intensity of induced reproductive conditions. In recent years, noticeable improvements in cancer management have led to longer survival, and fertility preservation has gained renewed relevance among initiatives devised to improve the quality of life of survivors (Martins et al., 2020; Ozdemir \& Bozdag, 2020).
A multi-herbal formulation locally called Loboob, a preparation containing specific proportions of different parts of eighteen medicinal plants processed with sugar and honey (Talib et al., 2017) to make a 20-ingredient semisolid compound (Bashir \& Afrin, 2019; Fahamiya et al., 2016), has been used in Traditional Persian Medicine (TPM) to treat male infertility (Rahman et al., 2014). Loboob has other spellings, such as Laboob or labub. There are official formulations of Loboob in the traditional medicine market, specifically in India and Iran. Although we found no articles published in English about the ingredients of Loboob, several studies on traditional medicine in Asia contain references to Laboob-e-kabeer and Laboob-e-Sagheer (Akhtar et al., 2010; Bano et al., 2018; Bashir \& Afrin, 2019; Fahamiya et al., 2016; Rahman et al., 2014; Talib et al., 2017). The formulation of Laboob-e-kabeer includes 60 ingredients, while Laboob-e-Sagheer is made from 20 ingredients. The Loboob formulation used in our study is a modified form of Laboob-e-Sagheer as explained in the Qarabadin Salehi with minor modifications (Zargaran \& Zarshenas, 2017).

To the best of our knowledge, no report has been previously published on the effect of Loboob on chemotherapy-induced male infertility (Bioos et al., 2015; Daneshfard $\&$ Jaladat, 2016). This study aimed to analyze the potential preservative power of Loboob on the sperm parameters of rats treated with a gonadotoxic alkylating agent.

\section{MATERIALS AND METHODS \\ Animals}

This study included 55 male Sprague-Dawley rats with an average weight of $225 \pm 25 \mathrm{gr}$ at the animal laboratory of Shiraz University of Medical Sciences (SUMS). The study was conducted in accordance with the $\mathrm{Na}$ tional Institutes of Health guidelines (Ethics Committee certificate of approval: IR.SUMS.REC.1393.7468). The rats were kept for two weeks in the animal laboratory until they adjusted to new conditions. During this period, the experiment rats were kept under standard humidity conditions in a 12-h light and darkness cycle, housed in $20 \times 30 \times 55 \mathrm{~cm}$ Makrolon cages with stainless steel lattice roofs and wire mesh floors. The cages were disinfected with washing solution every other day. They were kept at a temperature of about 25 degrees centigrade with free access to food (Daniran feeds and foods, Shiraz, Iran) and filtered water. 
Herbal Extract

The ingredients of the product were purchased from a herbal market in Shiraz, Iran. After identification (see voucher numbers in Table 1), plant specimens were deposited at the herbarium of the Phytopharmaceutical and Traditional Medicine incubator of SUMS. The scientific names

Table 1. Loboob Ingredients and their families, local name, used parts, percentages, main constituents and voucher numbers. Proportion of each ingredient showed in percentage.

\begin{tabular}{|c|c|c|c|c|c|c|c|}
\hline & Ingredient & Family & Local name & $\begin{array}{l}\text { Used } \\
\text { part }\end{array}$ & Main constituents & Percentage & $\begin{array}{c}\text { Voucher } \\
\text { No. }\end{array}$ \\
\hline 1 & Allium cepa L. & Amaryllidaceae & onion & s & $\begin{array}{c}\text { fatty acids, phenolic } \\
\text { compounds } \\
\text { (Yalcin \& Kavuncuoglu, 2014) }\end{array}$ & 3.45 & PTMI 107 \\
\hline 2 & $\begin{array}{l}\text { Alpinia } \\
\text { officinarum Hance }\end{array}$ & Zingiberaceae & $\begin{array}{l}\text { lesser } \\
\text { galangal }\end{array}$ & $r$ & $\begin{array}{c}\text { Volatile oil, phenolic } \\
\text { compounds } \\
\text { (Abubakar et al., 2018) }\end{array}$ & 3.45 & PTMI 108 \\
\hline 3 & $\begin{array}{l}\text { Boswellia carterii } \\
\text { Birdw. }\end{array}$ & Burseraceae & frankincense & o & $\begin{array}{c}\text { Volatile oil, boswellic } \\
\text { acids } \\
\text { (Iram et al., 2017) }\end{array}$ & 3.45 & PTMI 109 \\
\hline 4 & Brassica rapa L. & Brassicaceae & turnip & s & $\begin{array}{c}\text { Fatty acids } \\
\text { (Basnet et al., 2016) }\end{array}$ & 6.90 & PTMI 118 \\
\hline 5 & $\begin{array}{l}\text { Cinnamomum } \\
\text { zeylanicum Blume }\end{array}$ & Lauraceae & cinnamon & b & $\begin{array}{c}\text { Volatile oil } \\
\text { (Ribeiro et al., 2020) }\end{array}$ & 3.45 & PTMI 110 \\
\hline 6 & Cocos nucifera L. & Arecaceae & coconut & $f$ & $\begin{array}{c}\text { Fatty acids } \\
\text { (Roopan, 2016) }\end{array}$ & 6.90 & PTMI 101 \\
\hline 7 & $\begin{array}{l}\text { Corylus avellana } \\
\text { L. }\end{array}$ & Betulaceae & hazelnut & k & $\begin{array}{c}\text { Fatty acids } \\
\text { (Granata et al., 2017) }\end{array}$ & 6.90 & PTMI 102 \\
\hline 8 & Juglans regia L. & Juglandaceae & walnut & k & $\begin{array}{c}\text { Fatty acids } \\
\text { (Al-Snafi, 2018) }\end{array}$ & 6.90 & PTMI 103 \\
\hline 9 & $\begin{array}{l}\text { Lepidium } \\
\text { perfoliatum L. }\end{array}$ & Brassicaceae & $\begin{array}{l}\text { clasping pep- } \\
\text { perweed }\end{array}$ & s & $\begin{array}{c}\text { Fatty acids, gum } \\
\text { (Lazzeri et al., 2013) }\end{array}$ & 6.90 & PTMI 111 \\
\hline 10 & Mentha piperita L. & Lamiaceae & $\operatorname{mint}$ & I & $\begin{array}{c}\text { Volatile oil } \\
\text { (Mimica-Dukić et al., 2003) }\end{array}$ & 6.90 & PTMI 112 \\
\hline 11 & Piper cubeba L.F. & Piperaceae & tailed pepper & $f$ & $\begin{array}{l}\text { Phenolic compounds, } \\
\text { alkaloid, lignans } \\
\text { (Nahak \& Sahu, 2011; } \\
\text { Elfahmi et al., 2007) }\end{array}$ & 3.45 & PTMI 113 \\
\hline 12 & Piper nigrum L. & Piperaceae & pepper & $f$ & $\begin{array}{c}\text { Volatile oil, alkaloid } \\
\text { (Meghwal \& Goswami, 2013) }\end{array}$ & 3.45 & PTMI 114 \\
\hline 13 & Pistacia vera L. & Anacardiaceae & pistachio & k & $\begin{array}{c}\text { Fatty acids } \\
\text { (Shokraii, 1977) }\end{array}$ & 6.90 & PTMI 104 \\
\hline 14 & Prunus dulcis Mill. & Rosaceae & almond & k & $\begin{array}{c}\text { Fatty acids } \\
\text { (Mexis et al., 2011) }\end{array}$ & 6.90 & PTMI 105 \\
\hline 15 & $\begin{array}{l}\text { Sesamun indicum } \\
\text { L. }\end{array}$ & Pedaliaceae & sesame & s & $\begin{array}{c}\text { Fatty acids } \\
\text { (Uzun et al., 2007) }\end{array}$ & 6.90 & PTMI 106 \\
\hline 16 & Sugar & - & ------- & - & ------------------ & 6.90 & - \\
\hline 17 & $\begin{array}{l}\text { Syzygium } \\
\text { aromaticum (L.) } \\
\text { Merr.\& L.M.Perry }\end{array}$ & Myrtaceae & cloves & bu & $\begin{array}{l}\text { Volatile oil, phenolic } \\
\text { compounds } \\
\text { (Cortés-Rojas et al., 2014) }\end{array}$ & 3.45 & PTMI 115 \\
\hline 18 & $\begin{array}{l}\text { Withania } \\
\text { somnifera (L.) } \\
\text { Dunal }\end{array}$ & Solanaceae & ginseng & $r$ & $\begin{array}{c}\text { Steroidal lactones, } \\
\text { flavonoids, phenolic } \\
\text { compounds } \\
\text { (Dhanani et al., 2017) }\end{array}$ & 3.45 & PTMI 116 \\
\hline 19 & $\begin{array}{l}\text { Zingiber officinale } \\
\text { Roscoe }\end{array}$ & Zingiberaceae & ginger & rh & $\begin{array}{c}\text { Volatile oil } \\
\text { (Ali et al., 2008) }\end{array}$ & 3.45 & PTMI 117 \\
\hline 20 & Honey & - & ------- & - & - & $\begin{array}{l}(\times 3) \text { of } \\
\text { extract }\end{array}$ & - \\
\hline
\end{tabular}


of the plants were checked on http://www.theplantlist.org. The ingredients of Loboob were prepared based on a compound named Laboob-e-sagheer described in a medieval Persian pharmacopeia (Qarabadin Salehi) with minor modifications and removal of potentially harmful ingredients (Zargaran \& Zarshenas, 2017). Table 1 shows the scientific and English names of the ingredients, the used plant parts, and their proportions in the final product.

The ingredients were washed and dried thoroughly. Each was ground to a powder separately on a grinder, and then blended together into a homogenous mixture. A hydroalcoholic $(70 \%)$ extract of the powder was obtained after $72 \mathrm{~h}$ and submitted to a concentration process using a rotary apparatus (Büchi, Switzerland) at $37^{\circ} \mathrm{C}$. The concentrate was mixed with dewaxed honey $(1: 3)$ and homogenized through continuous stirring for 30 minutes. According to TPM clinical instructions, the final product was kept at room temperature in an airtight glass container for 40 days before use.

\section{Inducing Subfertility With Busulfan}

Similar to other alkylating agents, Busulfan may induce subfertility or infertility depending on length of exposure and dosage. According to our previous study on the toxic effects of different dosages of busulfan on the testicles of rats (Bahmanpour et al., 2017), we decided to use a single dose of $10 \mathrm{mg} / \mathrm{kg}$ intraperitoneal injection of busulfan in the rats included in this study to induce moderate reversible subfertility (Sigma-Aldrich Co, St. Louis, MO, USA).

\section{Animal Allocation}

This is a prospective randomized controlled study. Calculations performed on a statistical software package considering a margin of error of $5 \%$, statistical power of $80 \%$, and an effect size of $10 \%$ yielded a sample size of 50 rats. Considering the possibility of sample shedding due to the prolonged nature of this study, we included 55 rats randomly assigned into five groups, each containing eleven rats, as follows:

1) Control group $(\mathrm{C})$ received no medication.

2) Treatment group 1 (T1) received a single $10 \mathrm{mg} / \mathrm{kg}$ intraperitoneal injection of Busulfan.

3) Treatment group 2 (T2) received a single $10 \mathrm{mg} / \mathrm{kg}$ intraperitoneal injection of Busulfan and Loboob (35mg/ $\mathrm{kg}$ /day).

4) Treatment group 3 (T3) received a single $10 \mathrm{mg} / \mathrm{kg}$ intraperitoneal injection of Busulfan and Loboob $(70 \mathrm{mg} /$ $\mathrm{kg} /$ day).

5) Treatment group 4 (T4) received a single $10 \mathrm{mg} / \mathrm{kg}$ intraperitoneal injection of Busulfan and Loboob $(140 \mathrm{mg} /$ $\mathrm{kg} /$ day).

\section{Drug Administration}

Busulfan was administered in a single dose via intra-peritoneal injection on the first day of the study, while Loboob was given by gastric lavage starting from the $30^{\text {th }}$ day of the study for a period of 60 days. The total duration of the study was 104 days, with 90 days occurring after busulfan injection. The animals were weighed before busulfan injection and at the end of the study using a compact electronic scale with an accuracy of $0.01 \mathrm{gr}$ (SF-400C, Suofei electronic, Jiangsu, China).

\section{Sperm Suspension Preparation}

The rats were anesthetized with ether and slaughtered. They were placed in a supine position and had their abdomens cleaned with $70 \%$ ethanol; a vertical incision was made on the abdomen so that the fat layer and the connective tissue surrounding the vas deferens were resected. An incision was made $5 \mathrm{~cm}$ from the epididymis following the removal of the fat layer. A petri dish containing $5 \mathrm{~mL}$ of Ham's F-IO medium (Gibco BRL, Grand Island, Introduction NY, USA) was used to provide for the appropriate distribution of spermatozoa into the solution after transferring the primary 10-millimeter segment of the ductus deferens and epididymis. The spermatozoa were milked by squeezing with a forceps, which led to sperm exiting from the end of the tissue specimen. After one hour, the spermatozoa were hyperactive and distributed. The epididymis was rapidly transferred to a petri dish containing $1 \mathrm{ml}$ of RPMI-1640 and $100 \mathrm{mg} / \mathrm{ml}$ of BSA medium. This petri dish was placed in an incubator set at $37^{\circ} \mathrm{C}$.

\section{Sperm Viability}

Sperm viability was assessed based on eosin-nigrosin staining. One quantity of sperm suspension and two quantities of formulated $1 \%$ eosin with concentrated water (Merck, Darmstadt, Germany) were mixed. Then, an equal quantity of prepared nigrosin (Merck, Darmstadt, Germany) was poured into the mentioned mixture after 30 seconds. Qualified thin slides were inspected under a light microscope (Nikon E-200, Japan) at 40x magnification. In each sample, 100 spermatozoa were counted to determine the percentage of viable sperm. A colorless feature in spermatozoa indicated viability, while discoloration toward red indicated non-viable spermatozoa (WHO, 1999).

\section{Sperm Motility}

The sperm suspension was transferred onto a slide, which had been previously heated to $37^{\circ} \mathrm{C}$. Five microscopic fields were randomly studied to determine the motility of 200 spermatozoa in each sample using a light microscope (Nikon E-200, Japan) at 200x magnification. Classification was performed based on the moving style of sperm. Spermatozoa with rapid linear, slow linear, or circular movements were labeled as rapid progressive, slow progressive, or non-progressive, respectively. Neither linear nor circular sperm progression was marked as immotile (Momeni \& Daneshpajoh, 2012).

\section{Sperm Count}

Sperm count was performed using a Neubauer hemocytometer (Deep $0.1 \mathrm{~mm}$, LABART, Germany) at 400x magnification using a light microscope. The number of spermatozoa in four squares of the Neubauer chamber were counted. The mean was multiplied by $10^{6}$ to obtain the number of sperm cells per $\mathrm{mL}$ of semen. The whole sperms (with heads and tails) were counted. Counting was done based on WHO protocol (WHO, 1999).

\section{Sperm Morphology}

Slides of the suspension stained with $1 \%$ eosin $Y$ were prepared and dried in room air. Then the slides were fixed with $96 \%$ ethanol and stained with the Papanicolaou method. The slides were viewed on a light microscope at 1000x magnification and the proportions of sperm with normal morphology were calculated. Sperm with unstructured or dual heads, combined bodies and dual, segmented or angled tails were considered abnormal (Momeni \& Daneshpajoh, 2012).

\section{Statistical Analysis}

At first, the normal distribution of data was evaluated with the Kolmogorov-Smirnov test. Then, the Kruskal-Wallis non-parametric test was performed to show whether there was at least one group that differed from the others, shown by a $p$-value $<0.05$. Finally, a post-hoc test (Dunn-Bonferroni) was performed to determine the exact effect of Loboob on each parameter and group. Statistical analysis was performed using SPSS version 22.0 and $p<0.05$ was deemed significant. 


\section{RESULTS}

Forty-nine of the 55 rats included in the study survived until final analysis. All rats included in groups $\mathrm{C}, \mathrm{T} 1$ and T4 and 16 rats (eight from each group) from the T2 and T3 groups survived until final analysis.

The Kruskal-Wallis test showed that except for non-progressive motility ( $p$-value $=0.136)$, other variables had statistically significant values, which led to additional analysis with the Dunn-Bonferroni test. Loboob 70 and 140mg/ $\mathrm{kg} /$ day were powerful enough to significantly improve the mean proportions of progressive sperm ( $p$-value $=0.024$ and 0.01 , respectively) (Table 2 ).

All dosages of Loboob in the T2, T3 and T4 groups had statistically significant effects to improve mean slow motile sperm count $(p$-value $<0.005)$. Loboob at a dosage of $140 \mathrm{mg} / \mathrm{kg} /$ day improved sperm viability. At the dosages prescribed in this study, Loboob did not improve normal morphology or count or decrease immotile sperm count significantly ( $p$-value $>0.005)$.

Mean body weight was not affected by Loboob in our study. The intergroup details of positive $p$-values are demonstrated in Figures 1 and 2.

\section{DISCUSSION}

Chemotherapy-induced infertility has been mentioned as a burden on the quality of life of men of reproductive age. Some traditional medicine prescriptions are suggested to produce protective effects on semen parameters against specific chemotherapy agents (Ferdosi Khosroshahi et al., 2013; Mohammadghasemi et al., 2010; Qu et al., 2018; Zhang et al., 2020). In the present project, semen parameters were studied in rats with Busulfan-induced subfertility given Loboob at different dosages. Loboob improved the motility of slow sperm in all three used dosages in this study, but progressive sperm and viability were improved only with higher dosages. There are official formulations of
Loboob in the traditional medicine market. Laboob-e-kabeer and Laboob-e-Sagheer have been mentioned in traditional books and several reports on traditional medicine in Asia (Akhtar et al., 2010; Bano et al., 2018; Bashir \& Afrin, 2019; Fahamiya et al., 2016; Rahman et al., 2014; Talib et al., 2017) and listed under compound formulations or Murakkabat (Laboob-e-kabeer, Laboob-e-Sagheer) (Bashir \& Afrin, 2019).

Laboob-e-kabeer as a sexual desire invigorative (Muqawwi-e-Bah) with its aphrodisiac formulation was mentioned in previous studies (Rahman et al., 2014). Also, in our country, Loboob is a multi-herbal compound that can be prepared with several formulations based on TPM. We used a formulation with 20 components. The scientific and common names of the ingredients and the used parts and percentages are presented in detail in Table 1 . About $25 \%$ of the Loboob formulation that we used in our research contained 18 different medicinal herbal parts (four kernels, four seeds, three fruits, two roots, one oleo-gumresin, one bark, one leaf, one bud, and one rhizome) that were added to honey and sugar to make the total of 20 components as shown in Table 1 . Another 20-component formulation of Loboob with ten ingredients in common with the formulation that we used was described as effective for infertile men with sperm counts $\geq 0.5 \times 10^{6} / \mathrm{ml}$ (Bioos et al., 2015).

Despite the improvement seen in mean sperm count, no dosage of Loboob showed statistically significant effect on mean sperm counts. According to the literature, several components of Loboob have been described to affect sperm count. Cinnamomum zeylanicum Blume (cinnamon) has a modulating role on heat stress and decreased testis apoptosis (Türk et al., 2015). Sesamun indicum $L$ (sesame) might improve sperm count via its antioxidant properties (Khani et al., 2013). There is some controversy on the effects of allium cepa (onion) on sperm counts derived from the use of different parts of the plant (bulb

Table 2. Sperm parameters of rats with Busulfan-induced subfertility treated with different Loboob dosages.

\begin{tabular}{|c|c|c|c|c|c|c|}
\hline Variables & Control & Busulfan & $\begin{array}{c}\text { Busulfan } \\
+ \\
\text { 35mg/kg Loboob }\end{array}$ & $\begin{array}{c}\text { Busulfan } \\
+ \\
\text { 70mg/kg Loboob }\end{array}$ & $\begin{array}{c}\text { Busulfan } \\
+ \\
140 \mathrm{mg} / \mathrm{kg} \text { Loboob }\end{array}$ & $p$-value ${ }^{1}$ \\
\hline $\begin{array}{l}\text { Sperm } \\
\text { Count } \times 106(n)\end{array}$ & $87.20 \pm 10.61$ & $22.00 \pm 6.47^{\Perp}$ & $45.25 \pm 8.77$ & $53.25 \pm 20.19$ & $60.81 \pm 34.28$ & 0.000 \\
\hline $\begin{array}{l}\text { Progressive sperm } \\
\text { movement (\%) }\end{array}$ & $36.80 \pm 19.06$ & $1.36 \pm 3.10^{4, \bullet, *}$ & $15.25 \pm 16.88$ & $16.12 \pm 8.57$ & $19.45 \pm 9.75$ & 0.000 \\
\hline $\begin{array}{l}\text { Slow sperm } \\
\text { movement (\%) }\end{array}$ & $10.42 \pm 1.98$ & $1.09 \pm 1.64^{\mathbf{\Lambda}, \boldsymbol{n}, \bullet, *}$ & $8.87 \pm 4.73$ & $9.37 \pm 5.42$ & $11.90 \pm 10.59$ & 0.000 \\
\hline $\begin{array}{l}\text { Non-progressive } \\
\text { sperm }(\%)\end{array}$ & $22.66 \pm 6.20$ & $13.36 \pm 17.25$ & $26.75 \pm 8.11$ & $27.00 \pm 2.23$ & $24.00 \pm 9.01$ & 0.136 \\
\hline $\begin{array}{l}\text { Immotile sperm } \\
(\%)\end{array}$ & $6.00 \pm 2.70^{\mathrm{F}}$ & $26.87 \pm 16.60^{\wedge}$ & $24.37 \pm 11.62$ & $17.75 \pm 7.38$ & $10.44 \pm 8.07$ & 0.001 \\
\hline $\begin{array}{l}\text { Normal sperm } \\
\text { morphology }(\%)\end{array}$ & $85.60 \pm 7.96^{\mathrm{F}}$ & $57.90 \pm 22.25^{\wedge}$ & $61.75 \pm 8.87$ & $66.81 \pm 6.70$ & $73.22 \pm 8.17$ & 0.000 \\
\hline $\begin{array}{l}\text { Sperm viability } \\
(\%)\end{array}$ & $92.70 \pm 5.85^{\mathrm{t}, *}$ & $59.83 \pm 7.13^{\Delta, *}$ & $68.31 \pm 12.33$ & $71.56 \pm 7.10$ & $78.04 \pm 6.38$ & 0.000 \\
\hline Weight of rats (gr) & $484.09 \pm 53.85^{\mathrm{f}, \neq, \#}$ & $380.66 \pm 32.16^{\wedge}$ & $382.62 \pm 23.07$ & $388.42 \pm 27.68$ & $391.00 \pm 39.29$ & 0.000 \\
\hline
\end{tabular}

${ }^{1}$ Kruskal-Wallis test used

The values are mean \pm SD

$\Delta$ : Significant between control and Busulfan, $\mathbf{m}:$ Significant between Busulfan and Busulfan $+35 \mathrm{mg} / \mathrm{kg}$ Loboob, $\bullet$ : Significant between Busulfan and Busulfan $+70 \mathrm{mg} / \mathrm{kg}$ Loboob, *: Significant between Busulfan and Busulfan $+140 \mathrm{mg} / \mathrm{kg}$ Loboob, 1 : Significant between control and Busulfan $+35 \mathrm{mg} / \mathrm{kg}$ Loboob, $¥$ : Significant between control and Busulfan $+70 \mathrm{mg} / \mathrm{kg}$ Loboob, \# : Significant between control and Busulfan $+140 \mathrm{mg} / \mathrm{kg}$ Loboob 


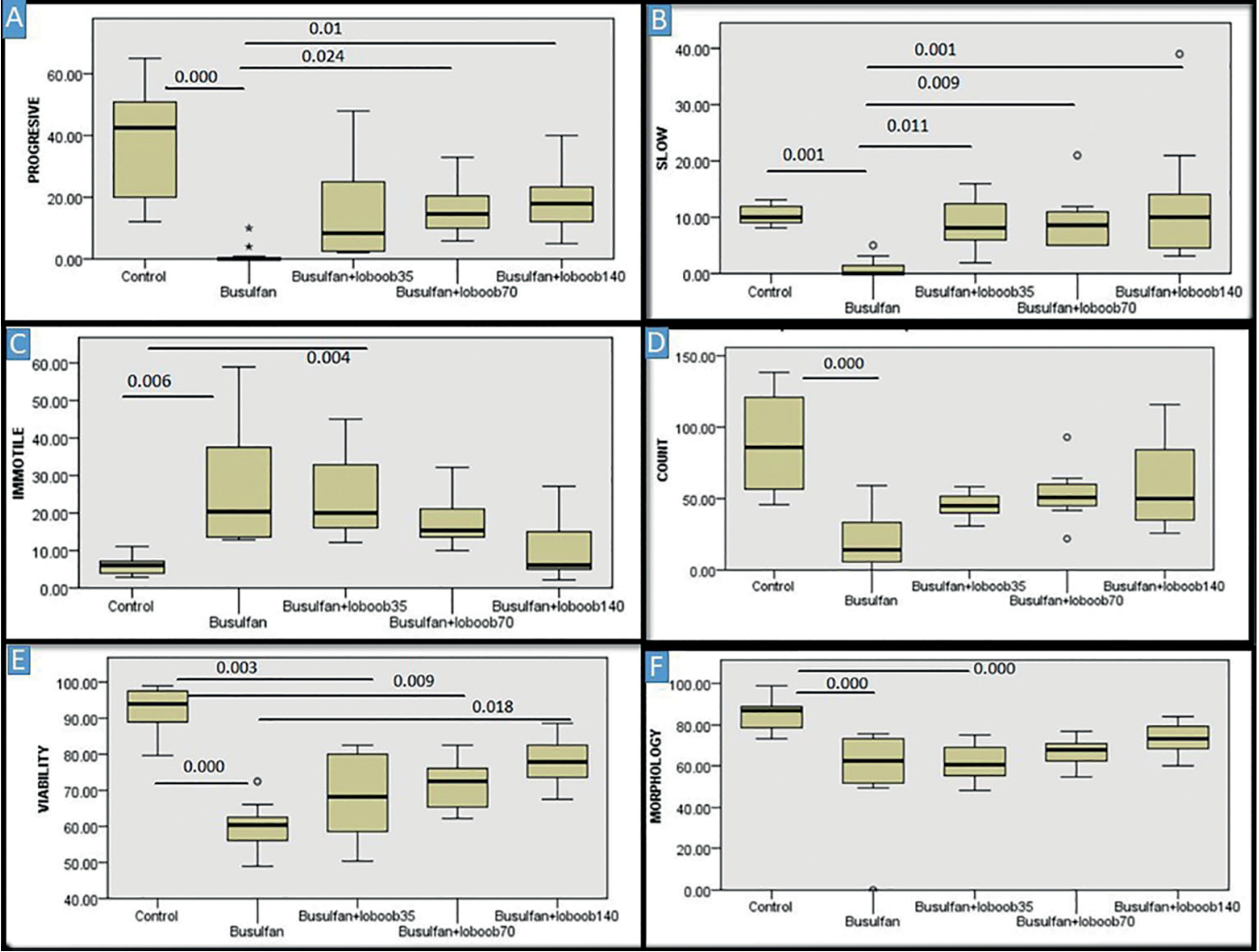

Figure 1. Result of post-hoc test (Dunn-Bonferroni) comparing each treated group for sperm parameters. $p$-values between the groups are shown on the line drawn to connect every compared two columns. A: $p$-values for progressive motility sperm B: $\mathrm{p}$-values for slow sperm C: $\mathrm{p}$-values for immotile sperm $\mathrm{D}$ : $p$-values for sperm count $\mathrm{E}: p$-values for viability $\mathrm{F}: p$-values for normal morphology.

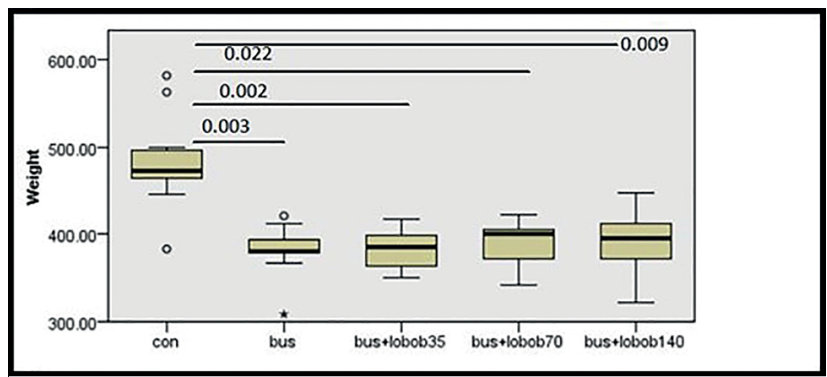

Figure 2. Result of post-hoc test (Dunn-Bonferroni) comparing each treated group in the aspect of body weight. $P$-values between the groups are shown on the line drawn to connect every compared two columns.

vs. seeds). The antioxidant activity of the onion bulb and serum testosterone increases associated with onion seeds might be responsible for enhancements in sperm counts (Khaki et al., 2009; Vahdani \& Khaki, 2014). Adeoye et al. (2018) reported possible negative dose dependent effects of the onion bulb on sperm counts. However, onion seeds were used to prepare Loboob in our study. The other contributing ingredient is Alpinia officinarum Hance (lesser galangal) with its component galangin leading to anti-oxidative effect (Kolangi et al., 2019). Effects arising from the anti-oxidant properties of Withania somnifera (ginseng) and hormonal effects caused by GABA mimetic features on gonadotropin releasing hormone, follicle-stimulating hormone, luteinizing hormone (LH) and testosterone have been described (Nasimi Doost Azgomi et al., 2018). Zingiber officinale (ginger) is supposed to affect sperm counts via its anti-oxidant properties, increases in testosterone and LH levels, and modification of nitric oxide levels leading to changes in vascular blood flow with final consequences on hormone production (Banihani, 2019). Incongruent to other ingredients, Piper nigrum L. (pepper) is supposed to have anti-spermatic effect (Mishra \& Singh, 2009). Lack of an effect of Loboob on sperm count might be attributed to the powerful side effects of Piper nigrum $L$ or other ingredients that have not been studied yet.

Loboob improved sperm motility in our study. All dosages of Loboob improved slow sperm while doses of 70 and $140 \mathrm{mg} / \mathrm{kg}$ had positive effects on progressive motility. Cocos nucifera $L$. (coconut) via its anti-oxidant properties in maintaining bioactivity of biological systems, cytokinins, and other components like sugar, vitamin, minerals and amino acids are considered effective at increasing sperm motility (Jimoh, 2020). Increasing blood serum omega- 6 and plant source of omega- 3 by Juglans regia (walnut) (Robbins et al., 2012), sugar component of Corylus avellana L. ( hazelnut) (Li \& Ross, 1988), and anti-oxidant properties of Sesamun indicum $L$ and Withania somnifera (Khani et al., 2013; Nasimi Doost Azgomi et al., 2018) might enhance motility. Although allium cepa may improve sperm motility by its antioxidant activity and alteration of ion channels permeability (Chae et al., 2017; Khaki et al., 2009), Adeoye et al. (2018) revealed a dose-dependent 
toxic effect of allium cepa bulb on sperm motility by increasing the incidence of abnormal sperm tail shapes. Our study used seeds of allium cepa, which might explain our different results. Mentha piperita L. (mint) may also improve motility (Tvrdá et al., 2018). Prunus dulcis Mill. (almond) enhances sperm motility via its unsaturated fatty acid component (Hussein \& Raheem, 2015). Protecting structural and functional membrane integrity as well as mitochondrial effects are the mechanisms described for Syzygium aromaticum (cloves) as a dose-dependent component (Mishra \& Singh, 2016; Santos et al., 2019). Protecting structural and functional membrane integrity as well as mitochondrial effects are the mechanisms described for Syzygium aromaticum (cloves) as a dose-dependent component $(36,37)$. Zingiber officinale may also affect motility via magnesium supplementation and some enzymatic pathways (Banihani, 2019).

Treatment with $140 \mathrm{mg} / \mathrm{kg}$ Loboob improved sperm viability in our study. This result can be attributed to Juglans regia by its omega 3 ingredients (Robbins et al., 2012), antioxidant and inhibition of apoptosis via the action of poly unsaturated fatty acids of allium cepa (Khaki et al., 2009). Prunus dulcis Mill. is also supposed to enhance sperm viability (Hussein \& Raheem, 2015). Sperm viability is enhanced by Prunus dulcis Mill. (35). Besides, Syzygium aromaticum positively affects sperm viability by protecting structural and functional membrane integrity (Santos et al., 2019). It should be considered that Piper. cubeba is used as a critical ingredient in many formulations such as Laboob-e-Sagheer (Bano et al., 2018). Corylus colurna is a component of various complex Unani formulations such as Khurma, Laboob-e- Sagheer, Laboob-e-Kabeer, and is used as an aphrodisiac when combined with honey (Akhtar et al., 2010).

Loboob did not statistically change the mean body weight of the rats included in the study. However, Cinnamomum zeylanicum Blume can increase body weight via its inhibitory effect on heat stress changes and by increasing appetite and feeding efficacy (Türk et al., 2015). Corylus avellana $L$. can affect via its lipid composition (Savage \& McNeil, 1998). On the contrary, an anti-obesity role has been described for Alpinia officinarum Hance in the literature due to the combined effects of various phytochemicals such as flavonoids and phenolics (Xia et al., 2010). Loboob did not significantly increase the mean body weight of the rats with busulfan-induced subfertility included in this study.

Although improvements were seen in mean sperm morphology in the rats treated with Loboob, the differences in relation to untreated rats were not statistically significant. Micronutrients and omega 3 in Juglans regia (Robbins et al., 2012) are considered to improve sperm morphology. It should be noticed that there is some controversy about the impact of allium cepa on sperm morphology. Although Khaki et al. (2009) found that allium cepa did not affect sperm morphology, a toxic effect of allium cepa bulb on sperm morphology with findings such as absence of the head or tail and having an angulated or twisted tail was described in another study (Adeoye et al., 2018). High levels of reactive oxygen species (ROS) are detected among abnormally shaped sperms. Alpinia officinarum Hance might reduce the production of ROS via its phytochemicals, mainly galangin. It also diminishes apoptosis by caspase inhibition and regulation of $\mathrm{BCl}-2$ and $\mathrm{Bax}$ expression (Kolangi et al., 2019). Another anti-oxidant that protects against DNA damage is Prunus dulcis Mill (Hussein \& Raheem, 2015).

As far as we know, this is the first study that analyzed male rats with busulfan-induced subfertility to show and com- pare the protective effects of Loboob in different dosages on sperm parameters in a randomized trial. Our study showed that Loboob decreased some of the undesirable effects of busulfan on male rat sperm parameters in a dose-dependent manner. It is believed that this traditional multi-herbal formulation might induce similar valuable therapeutic effects not only after busulfan chemotherapy, but also for men in the general population suffering from infertility or subfertility as it has been traditionally used. We think that more studies with higher dosages of Loboob are required to find the best therapeutic dosage. We acknowledge the limitations of this study, which include the fact that it was performed on rats. Human studies using different Loboob dosages are warranted to see the possible effects or side effects of this herbal electuary as a possible human therapeutic modality. Different methods of preparation, extraction procedures, alterations in the bioavailability of herbal ingredients, and possible allergy or toxicity of the different components should be evaluated, especially in human studies. Future human studies may find a role for Loboob in the management of male subfertility or for protection of the testes from side effects of alkylating chemotherapeutic agents.

\section{CONCLUSION}

This study showed that Loboob, a traditional Persian multi-herbal formulation used for male infertility, has dose-dependent protective effects on several sperm parameters in rats with busulfan-induced subfertility. Loboob improved the motility of slow spermatozoa in all three dosages used in this study, while progressive motility improved in dosages of 70 and $140 \mathrm{mg} / \mathrm{kg} /$ day, and viability improved only in the dosage of $140 \mathrm{mg} / \mathrm{kg} / \mathrm{day}$.

\section{ACKNOWLEDGMENT}

This article was partly extracted from a thesis written by Adel Noori in partial fulfillment of the requirement for the degree of Doctor of Medicine (grant number: 7468). The authors would like to thank the staff at the animal laboratory and the Medicinal Plants School affiliated to SUMS for their expert cooperation.

\section{Author Contributions}

S.B. designed, created models and supervised the study; M.K. performed the biological experiments, collected data, and wrote the original draft; F.K. performed the biological experiments, collected data, and wrote the original draft; P.B. provided the study materials and wrote the original draft; A.N. collected data and wrote the original draft; M.H.D. designed and supervised the research; T.P. supervised the study and provided the study material; F.S.N. supervised the study and provided the study material; N.Z. performed statistical analysis and supervised the study; N.N. wrote the original draft and analyzed data; B.N.J. designed the study provided the study materials, wrote the original draft, and supervised the study. All of the authors reviewed and approved the final manuscript.

Funding: This work was financially supported by SUMS (grant number of 7468).

\author{
Corresponding author: \\ Bahia Namavar Jahromi \\ Department of OB-GYN \\ School of Medicine \\ Shiraz University of Medical Sciences \\ Shiraz, Iran. \\ E-mail: namavarprc@gmail.com
}




\section{REFERENCES}

Abubakar IB, Malami I, Yahaya Y, Sule SM. A review on the ethnomedicinal uses, phytochemistry and pharmacology of Alpinia officinarum Hance. J Ethnopharmacol. 2018;224:45-62. PMID: 29803568 DOI: 10.1016/j. jep.2018.05.027

Adeoye OJ, Olayinka OA, Bernard SA, Sikiru OA, Kofoworola OI, Olufemi OJ, Adekunle AA. Testicular and spermatotoxic potential of methanol extract of red cultivar Allium cepa in rats. J Complement Integr Med. 2018;15. PMID: 30020888 DOI: $10.1515 /$ jcim-2017-0102

Akhtar P, Ali M, Sharma MP, Waris MD, Hasan H, Ali B, Chaudhary N, Khan M, Ali A, Najib S, Farooqi H, Nawaz Khan $\mathrm{H}$. Development of Quality Standards of Corylus colurna (Linn.) Fruit. J Ecobiotechnol. 2010;2:14-20.

Al-Snafi AE. Chemical constituents, nutritional, pharmacological and therapeutic importance of Juglans regia-a review. IOSR J Pharm. 2018;8:1-21.

Ali BH, Blunden G, Tanira MO, Nemmar A. Some phytochemical, pharmacological and toxicological properties of ginger (Zingiber officinale Roscoe): a review of recent research. Food Chem Toxicol. 2008;46:409-20. PMID: 17950516 DOI: $10.1016 / j$.fct.2007.09.085

Bahmanpour S, Jahromi BN, Koohpeyma F, Keshavarz M, Bakhtari A. Effects of different doses and time-dependency of Busulfan on testes parameters and spermatogenesis in a rat model: A quantitative stereological study. J Adv Med Sci Appl Technol. 2017;3:155-62.

Banihani SA. Effect of ginger (Zingiber officinale) on semen quality. Andrologia. 2019;51:e13296. PMID: 31012134 DOI: 10.1111 /and.13296

Bano H, Jahan N, Makbul SAA, Kumar BN, Husain S, Sayed A. Effect of Piper cubeba L. fruit on ethylene glycol and ammonium chloride induced urolithiasis in male Sprague Dawley rats. Integr Med Res. 2018;7:358-65. PMID: 30591890 DOI: $10.1016 /$ j.imr.2018.06.005

Bashir F, Afrin Z. Zanjabeel (Zingiber offcinale) Transformation of Culinary Spice to a multi-functional Medicine. J Drug Deliv Ther. 2019;9:721-5. DOI: $10.22270 /$ jddt. v9i4-s.3299

Basnet RK, Del Carpio DP, Xiao D, Bucher J, Jin M, Boyle K, Fobert P, Visser RG, Maliepaard C, Bonnema G. A Systems Genetics Approach Identifies Gene Regulatory Networks Associated with Fatty Acid Composition in Brassica rapa Seed. Plant Physiol. 2016;170:568-85. PMID: 26518343 DOI: $10.1104 /$ pp.15.00853

Bioos S, Nazem E, Keshavarz M, Siahpoosh MB, Sohrabvand $F$, Sohanaki $H$, Nejatbakhsh F. A Traditional Iranian Medicine (Majoon-e Loboob) for Idiopathic Male Infertility: A Case Series. Trad Integr Med. 2015;1:47-51.

Chae MR, Kang SJ, Lee KP, Choi BR, Kim HK, Park JK, Kim CY, Lee SW. Onion (Allium cepa L.) peel extract (OPE) regulates human sperm motility via protein kinase C-mediated activation of the human voltage-gated proton channel. Andrology. 2017;5:979-89. PMID: 28805023 DOI: 10.1111/andr.12406
Cortés-Rojas DF, de Souza CR, Oliveira WP. Clove (Syzygium aromaticum): a precious spice. Asian Pac J Trop Biomed. 2014;4:90-6. PMID: 25182278 DOI: 10.1016/ S2221-1691(14)60215-X

Daneshfard B, Jaladat AM. Male infertility and diet: a perspective of traditional persian medicine. Galen Med J. 2016;5:103-4.

Dhanani T, Shah S, Gajbhiye N, Kumar S. Effect of extraction methods on yield, phytochemical constituents and antioxidant activity of Withania somnifera. Arab J Chem. 2017;10:S1193-9. DOI: 10.1016/j.arabjc. 2013.02.015

Elfahmi, Ruslan K, Batterman S, Bos R, Kayser O, Woerdenbag HJ, Quax WJ. Lignan profile of Piper cubeba, an Indonesian medicinal plant. Biochem System Ecol. 2007;35:397-402.

Fahamiya N, Shiffa M, Aslam M, Farzana M. Unani perspective of Khatmi (Althaea officinalis). J Pharmacogn Phytochem. 2016;5:357-60.

Ferdosi Khosroshahi A, Bakhtiari M, Rad JS, Koroji M, Roshangar $L$, Janzadeh A, Kerdari M, Jameie B. Study of the effect of exogenous melatonin on sperm fertility in busulfan induced oligospermic of pinealectomized rat. Razi J Med Sci. 2013;20:77-86.

Granata MU, Bracco F, Gratani L, Catoni R, Corana F, Mannucci B, Sartori F, Martino E. Fatty acid content profile and main constituents of Corylus avellana kernel in wild type and cultivars growing in Italy. Nat Prod Res. 2017;31:204-9. PMID: 27605244 DOI: 10.1080/14786419.2016.1217204

Hussein RH, Raheem SA. Effects of almond seed oil extraction and some antioxidant agents on sperm quality in alloxan-induced diabetes mellitus rat. Int J Curr Microbiol Appl Sci. 2015;4:93-104.

Iram F, Khan SA, Husain A. Phytochemistry and potential therapeutic actions of Boswellic acids: A mini-review. Asian Pac J Trop Biomed. 2017;7:513-23. DOI: 10.1016/j. apjtb.2017.05.001

Jimoh OA. Potential of coconut water to enhance fresh semen quality and fertility in rabbits. Trop Anim Health Prod. 2020;52:249-55. PMID: 31302834 DOI: $10.1007 /$ s11250019-02011-z

Khaki A, Fathiazad F, Nouri M, Khaki AA, Khamenehi HJ, Hamadeh M. Evaluation of androgenic activity of allium cepa on spermatogenesis in the rat. Folia Morphol (Warsz). 2009;68:45-51. PMID: 19384830

Khani B, Bidgoli SR, Moattar F, Hassani H. Effect of Sesame on Sperm Quality of Infertile Men. J Res Med Sci. 2013;18: 184-7.

Kolangi F, Shafi $H$, Memariani $Z$, Kamalinejad M, Bioos S, Jorsaraei SGA, Bijani A, Shirafkan H, Mozaffarpur SA. Effect of Alpinia officinarum Hance rhizome extract on spermatogram factors in men with idiopathic infertility: A prospective double-blinded randomised clinical trial. Andrologia. 2019;51:e13172. PMID: 30378695 DOI: $10.1111 /$ and. 13172 
Lazzeri L, Malaguti L, Bagatta M, D’Avino L, Ugolini L, De Nicola GR, Casadei N, Cinti S, Matteo R, Iori R. Characterization of the main glucosinolate content and fatty acid composition in non-food Brassicaceae seeds. Acta Hortic. 2013;1005:331-8. DOI: $10.17660 /$ ActaHortic. 2013.1005.38

Li L, Ross JD. Fructose 1,6-bisphosphatase in seeds of Corylus avellana. Phytochemistry. 1988;27:1977-80. DOI: 10.1016/0031-9422(88)80081-5

Martins AD, Agarwal A, Baskaran S, Pushparaj PN, Ahmad G, Panner Selvam MK. Alterations of Spermatozoa Proteomic Profile in Men with Hodgkin's Disease Prior to Cancer Therapy. World J Mens Health. 2020;38:521-34. PMID: 31385466 DOI: $10.5534 /$ wjmh. 190012

Meghwal M, Goswami TK. Piper nigrum and piperine: an update. Phytother Res. 2013;27:1121-30. PMID: 23625885 DOI: $10.1002 /$ ptr.4972

Mexis SF, Riganakos KA, Kontominas MG. Effect of irradiation, active and modified atmosphere packaging, container oxygen barrier and storage conditions on the physicochemical and sensory properties of raw unpeeled almond kernels (Prunus dulcis). J Sci Food Agric. 2011;91:634-49. PMID: 21302317 DOI: $10.1002 /$ jsfa.4225

Mimica-Dukić N, Bozin B, Soković M, Mihajlović B, Matavulj $M$. Antimicrobial and antioxidant activities of three Mentha species essential oils. Planta Med. 2003;69:413-9. PMID: 12802721 DOI: $10.1055 / \mathrm{s}-2003-39704$

Mishra RK, Singh SK. Antispermatogenic and antifertility effects of fruits of Piper nigrum L. in mice. Indian J Exp Biol. 2009;47:706-14. PMID: 19957882

Mishra RK, Singh SK. Biphasic effect of Syzygium aromaticum flower bud on reproductive physiology of male mice. Andrologia. 2016;48:923-32. PMID: 26840772 DOI: 10.1111/and. 12533

Mohammadghasemi F, Faghani M, Jahromi SK. The protective effects of melatonin on the histological changes of testis in busulfan-treated adult mice. J Reprod Infertil. 2010;11:67-76.

Momeni HR, Daneshpajoh F. Protective effect of vitamin E on sperm parameters in adult rat treated with para-nonylphenol. J Cell Tissue. 2012;2:415-24.

Nahak G, Sahu RK. Phytochemical evaluation and antioxidant activity of Piper cubeba and Piper nigrum. J Appl Pharma Sci. 2011;1:153-7.

Nasimi Doost Azgomi R, Zomorrodi A, Nazemyieh $\mathrm{H}$, Fazljou SMB, Sadeghi Bazargani H, Nejatbakhsh F, Moini Jazani A, Ahmadi AsrBadr Y. Effects of Withania somnifera on Reproductive System: A Systematic Review of the Available Evidence. Biomed Res Int. 2018;2018:4076430. PMID: 29670898 DOI: $10.1155 / 2018 / 4076430$

Nahak G, Sahu RK. Phytochemical evaluation and antioxidant activity of Piper cubeba and Piper nigrum. J Appl Pharma Sci. 2011;1:153-7.
Nasimi Doost Azgomi R, Zomorrodi A, Nazemyieh H, Fazljou SMB, Sadeghi Bazargani $H$, Nejatbakhsh F, Moini Jazani A, Ahmadi AsrBadr Y. Effects of Withania somnifera on Reproductive System: A Systematic Review of the Available Evidence. Biomed Res Int. 2018;2018:4076430. PMID: 29670898 DOI: $10.1155 / 2018 / 4076430$

Ozdemir ZN, Bozdag SC. Hematological Malignancies and Fertility. Adv Exp Med Biol. 2020;1288:103-15. PMID: 32124411 DOI: 10.1007/5584_2020_490

Qu N, Kuramasu M, Hirayanagi Y, Nagahori K, Hayashi S, Ogawa Y, Terayama H, Suyama K, Naito M, Sakabe K, Itoh M. Gosha-Jinki-Gan Recovers Spermatogenesis in Mice with Busulfan-Induced Aspermatogenesis. Int J Mol Sci. 2018;19:2606. PMID: 30177609 DOI: 10.3390/ijms19092606

Rahman A, Ali SJ, Ahmad I, Aslam M. A Review Paper on Jima (Sexual Intercourse)-in the Light of Legend Greek-Arab Philosophers with Special References. Int J Health Sci Res. 2014;4:342-6.

Ribeiro PRE, Montero IF, Saravia SAM, Ferraz VP, Santos RA, Marcia JAF, Linhares BM. Chemical composition and antioxidant activity in the essential oil of Cinnamomum zeylanicum Nees with medicinal interest. J Med Plants Res. 2020;14:326-30. DOI: 10.5897/JMPR2020.6966

Robbins WA, Xun L, FitzGerald LZ, Esguerra S, Henning SM, Carpenter CL. Walnuts improve semen quality in men consuming a Western-style diet: randomized control dietary intervention trial. Biol Reprod. 2012;87:101. PMID: 22895856 DOI: $10.1095 /$ biolreprod.112.101634

Roopan SM. An Overview of Phytoconstituents, Biotechnological Applications, and Nutritive Aspects of Coconut (Cocos nucifera). Appl Biochem Biotechnol. 2016;179:130924. PMID: 27052209 DOI: $10.1007 /$ s12010-016-2067-y

Santos MVO, da Silva AM, Praxedes ÉA, Borges AA, Teles Filho ACA, Souza-Junior JBF, Bertini LM, Silva AR, Pereira AF. Antioxidant effects of the essential oil of Syzygium aromaticum on bovine epididymal spermatozoa. Andrologia. 2019;51:e13448. PMID: 31642101 DOI: 10.1111/and.13448

Savage GP, McNeil DL. Chemical composition of hazelnuts (Corylus avellana L.) grown in New Zealand. Int J Food Sci Nutr. 1998;49:199-203. PMID: 10616661 DOI: $10.3109 / 09637489809086412$

Shokraii EH. Chemical composition of the pistachio nuts (Pistacia vera L.) of Kerman, Iran. J Food Sci. 1977;42:2445. DOI: $10.1111 /$ j.1365-2621.1977.tb01261.x

Talib M, Aslam M, Ahmad A, Asif M, Qamar W, Chaudhary $S$. An overview of a honeyed Unani blood purifier: Sharbat Unnab. World J Pharm Res. 2017;791-803. DOI: 10.20959/wjpr20177-8860

Tansaz M, Adhami S, Mokaberinejad R, Namavar Jahromi B, Atarzadeh F, Jaladat AM. An overview of the causes and symptoms of male infertility from the perspective of traditional persian medicine. Iran J Obstet Gynecol Infertil. 2016;18:11-7. 
Türk G, Şimşek ÜG, Çeribaşı AO, Çeribaşı S, Özer Kaya Ş, Güvenç M, Çiftçi M, Sönmez M, Yüce A, Bayrakdar A, Yaman M, Tonbak F. Effect of cinnamon (Cinnamomum zeylanicum) bark oil on heat stress-induced changes in sperm production, testicular lipid peroxidation, testicular apoptosis, and androgenic receptor density in developing Japanese quails. Theriogenology. 2015;84:365-76. PMID: 25913274 DOI: $10.1016 / j$.theriogenology.2015.03.035

Tvrdá E, Konečná N, Zbyňovská K, Lukáč, N. Antioxidant Effects of Peppermint (Mentha piperita) Extract on the Oxidative Balance of Rabbit Spermatozoa. J Adv Agric Technol. 2018;5:117-22. DOI: http://dx.doi.org/10.18178/ joaat.5.2.117-122 DOI: 10.18178/joaat.5.2.117-122

Uzun B, Arslan C, Karhan M, Toker C. Fat and fatty acids of white lupin (Lupinus albus L.) in comparison to sesame (Sesamum indicum L.). Food Chem. 2007;102:45-9. DOI: 10.1016/j.foodchem.2006.03.059

Vahdani V, Khaki A. Effect of Allium cepa seed extract on serum testosterone in rats. Crescent J Med Biol Sci. 2014;1:110-2.
WHO - World Health Organization. WHO laboratory manual for the examination of human semen and sperm-cervical mucus interaction. Cambridge: Cambridge University Press; 1999. PMID: 21919944 DOI: 10.1111/j.1439-0272.2011.01228.x

Xia DZ, Yu XF, Wang HM, Ren QY, Chen BM. Anti-obesity and hypolipidemic effects of ethanolic extract from Alpinia officinarum Hance (Zingiberaceae) in rats fed high-fat diet. J Med Food. 2010;13:785-91. PMID: 20482258 DOI: 10.1089/jmf.2009.1235

Yalcin $\mathrm{H}$, Kavuncuoglu $\mathrm{H}$. Physical, chemical and bioactive properties of onion (Allium cepa L.) seed and seed oil. J Appl Bot Food Qual. 2014;87-92.

Zargaran A, Zarshenas MM. The History of Pharmacopeias in Iran (Persia): From Antiquity to Current Era. In: Working Group History of Pharmacopeia, International Society for the History of Pharmacy; 2017. Available at: http://www. histpharm.org/ISHPWG\%20Iran.pdf

Zhang K, Weng H, Yang J, Wu C. Protective effect of Liuwei Dihuang Pill on cisplatin-induced reproductive toxicity and genotoxicity in male mice. J Ethnopharmacol. 2020;247:112269. PMID: 31610261 DOI: $10.1016 /$ j.jep.2019.112269 